Hanane Amrani-Allalou ${ }^{1}$ Lila Boulekbache-Makhlouf / Paula Mapelli-Brahm ${ }^{3}$ / Sabrina Sait ${ }^{1,4}$ / Gian Carlo Tenore ${ }^{5}$ / Akila Benmeziane ${ }^{1}$ / Nabil Kadri ${ }^{1,4}$ / Khodir Madani ${ }^{6,7}$ / Antonio Jesús Meléndez Martínez ${ }^{3}$

\title{
Antioxidant activity, carotenoids, chlorophylls and mineral composition from leaves of Pallenis spinosa: an Algerian medicinal plant
}

\author{
${ }^{1}$ Biologie Physico-Chimique, Laboratoire de Biomathématiques, Biophysique, Biochimie, et Scientométrie, Faculté des \\ Sciences de la Nature et de la Vie, Université de Bejaia, Bejaia 06000, Algérie, E-mail: allalouhanane@hotmail.com, \\ saitsabrina@gmail.com, benmezianeakila@yahoo.fr, kadri.montp2@gmail.com \\ ${ }^{2}$ Food sciences, Université A.Mira de Bejaia, Bejaia 06000, Algeria, E-mail: lilaboulekbachemakhlouf@yahoo.fr \\ ${ }^{3}$ Food Colour \& Quality Lab., Dpt. of Nutrition \& Food Science, Universidad de Sevilla, Seville, Spain, E-mail: \\ paulitra84@hotmail.com, ajmelendez@us.es \\ ${ }^{4}$ Département de Biologie, Faculté des sciences de la Nature et de la Vie et Sciences de la Terre, Université de Bouira, Bouira \\ 10000, Algérie, E-mail: saitsabrina@gmail.com, kadri.montp2@gmail.com \\ ${ }^{5}$ Department of Pharmacy, University of Naples “Federico II" Via Domenico Montesano, Via Domenico Montesano, 49 Napoli, \\ Campania 80131, Italy, E-mail: giancarlo.tenore@unina.it \\ ${ }^{6}$ Laboratoire de Biomathématiques, Biophysique, Biochimie, et Scientométrie, Faculté des Sciences de la Nature et de la Vie, \\ Université de Bejaia, Bejaia 06000, Algérie, E-mail: madani28dz2002@yahoo.fr \\ ${ }^{7}$ Centre de recherche en technologie agro-alimentaire, Route de tergua-ouzemour, 06000, Bejaia, Algérie, E-mail: \\ madani28dz2002@yahoo.fr
}

\begin{abstract}
:
Background: Plant and medicinal herbs are important sources of bioactive compounds and minerals that can play a role in preventing various diseases and they are considered a factor indispensable for the proper functioning of the human body.

Methods: We investigated the content of carotenoids and chlorophylls of leaves from Pallenis spinosa (P. spinosa), as well as their antioxidant activity and mineral composition then, we optimized the solvent extraction for the recovery of total carotenoids and chlorophylls using spectrophotometric method. Finally, we tested the antioxidant activity of the optimized extract by three assays (DPPH, ABTS and FRAP) and we determined the mineral composition by Emission Spectrometer Induced Couple Plasma (ICP).

Results: Carotenoid (CART), chlorophylls $(\mathrm{CHLa}+\mathrm{b})$, chlorophyll a (CHLA), chlorophyll b (CHLB) contents were about $36.337 \pm 0.312 ; 347.769 \pm 6.326 ; 224.286 \pm 5.601 ; 123.483 \pm 1.339 \mathrm{mg} / 100 \mathrm{~g}$ dw, respectively. We revealed an interesting antioxidant capacity by the tested extract (DPPH: $127.522 \pm 1.406 \mathrm{mmol} \mathrm{ET} / \mathrm{Kg}_{\mathrm{dw}}$, ABTS: $104.827 \pm 1.222 \mathrm{mmol} \mathrm{ET} / \mathrm{Kg}_{\mathrm{dw}}$ and FRAP $\left.71.89 \pm 0.495 \pm 0.994 \mathrm{mmol} \mathrm{ET} / \mathrm{Kg}_{\mathrm{dw}}\right)$. Carotenoids and chlorophylls content correlate positively with the antioxidant activity of $P$. spinosa leaves extract $(\mathrm{r}=0.646-0.986)$. Eight minerals have been detected $(\mathrm{Mg}, \mathrm{Ca}, \mathrm{P}, \mathrm{Fe}, \mathrm{Mn}, \mathrm{Zn}, \mathrm{Cu}$ and $\mathrm{Cr}$ ), $\mathrm{Mg}$ and $\mathrm{Ca}$ being the predominant ones (6479.32 \pm 48.33 and $3851.88 \pm 130.63 \mathrm{mg} / \mathrm{Kg}$, respectively).

Conclusions: These results have shown that $P$. spinosa leaves are a good source of carotenoids and chlorophylls with a potent antioxidant potential with high amount of minerals.
\end{abstract}

Keywords: antioxidant activity, carotenoids, chlorophylls, extraction, mineral composition, Pallenis spinosa DOI: 10.1515/jcim-2017-0081

Received: June 5, 2017; Accepted: April 13, 2019

\section{Introduction}

Phytochemicals have been receiving an increased attention for their important health benefits, providing a potential protection against several bimolecular damages, among these compounds we can cite carotenoids and chlorophylls [1]. 
Carotenoids are natural pigments which participate in the physiological processes such as respiration, photosynthesis and regulation of growth and development [2]. Carotenoids are also occurred in leafy vegetables with green color where chlorophylls cover their color (lettuce, pepper, spinach, etc.). Carotenoids are beneficial to humans, because some of them show vitamin A and antioxidant activities.

The consumption of carotenoids is inversely related to the risk of developing certain diseases [3], such as coronary heart dysfunction, cancers and ophthalmological diseases such as macular degeneration and cataract $[4,5]$. They contribute in the immune response by enhancing macrophage, cytotoxic T cell and natural killer cell tumoricidal capacities, as well as increase the production of certain interleukins [6]. Carotenoids have been reported for the effect on intracellular signaling cascades, thereby influencing gene expression and protein translation. By blocking the translocation of nuclear factor $\mathrm{kB}$ to the nucleus, carotenoids are able to interact with the nuclear factor $\mathrm{kB}$ pathway and thus inhibit the downstream production of inflammatory cytokines [69]. They contribute also to the process of vision, and are considered as a good supplement for the development of body cells [10].

Due to their essential roles in photosynthesis, chlorophylls are the most photosynthetic pigments present in algae, bacteria and higher plants. These photochemical compounds have been reported to possess benefits to human health such as antimutagenic effect, antigeno-toxic properties and potent antioxidant capacity by scavenging the free radicals and preventing the lipid oxidation [3, 6, 11-13], they have been reported to their anti-inflammatory and wound healing properties $[13,14]$. Chlorophylline (chlorophyll derivatives) is responsible for the increasing immune defense by its action on immune cells [13]. Some studies have reported its beneficial effect against cancer $[3,15]$ by forming complexes with carcinogenic chemical molecules tobacco [15] and heterocyclic amines from cooked meat [16].

Trace elements have also an importance on health and their role in traditional medicines have been reported in many published works [17-19]. They are essential components of proteins (hemoprotein, hemoglobin and hormones) and vitamins; in low dose they play an important role in the biochemical and essential enzymatic functions. They contribute also to the structure of bones and teeth [17-19] and are associated with heart function, muscle contraction, nerve conduction and to the homeostasis [18].

The large family of Asteraceae (=Compositae) contains $25,000-30,000$ species belonging to over 1,000 genera [20]. Many species have been used as sources of rubber, medicines, edible oils, vegetables and pesticides, and some of them are popular ornamental plants. P. spinosa (L.) Cass (Buphthalmum spinosum L.) belongs to the family of Asteraceae, and the tribe of Inuleae [20]. The genus Pallenis is distributed in southern Europe, northern Africa, the Canary Islands, the Middle East and in the Mediterranean region, especially in the desert, and coastal habitats [21].

Limited studies have been conducted on the selected health effects of the proposed plant, and to the best of our knowledge no study has been carried out on its pigments (carotenoids and chlorophylls) and mineral composition. The main objectives of this paper were: (1) the optimization of the solvent extraction of CRTS and CHLS; (2) evaluation of the antioxidant activity of the optimized extract and (3) determination of the mineral composition from leaves of $P$. spinosa.

\section{Materials and methods}

\section{Plant material}

P. spinosa plant was collected at flowering stage in May 2015, from Chabet-el-Ameur in Boumerdès, located in the East of Algiers $\left(36^{\circ} 38^{\prime} 00^{\prime \prime} \mathrm{N}, 3^{\circ} 42^{\prime} 00^{\prime \prime} \mathrm{E}\right.$ ). Leaves were separated manually, washed with distilled water and air dried at the shade for 20 days; then they were grounded into a fine powder using an electrical grinder (IKA model-A11, Staufen, Baden-Württemberg, Germany). The obtained powder was passed through a standard sieve $(125 \mu \mathrm{m})$ and only the fraction with particle size $<125 \mu \mathrm{m}$ was collected and stored at room temperature $\left(26^{\circ} \mathrm{C}\right)$ in an airtight polythene bag before ready for analyses.

\section{Chemicals and standards}

The extraction solvents were of analytical grade. Other chemicals were purchased from Sigma. 


\section{Extraction of pigments}

The extraction of pigments has been done according to the method recommended by Lichtenthaler [22]. Different solvents were tested (Acetone $100 \%$, aqueous acetone $80 \%$, diethyl ether $100 \%$, ethanol $95 \%, \mathrm{MeOH} 90 \%$ and $\mathrm{MeOH} 100 \%)$. The obtained extracts were stored under dry nitrogen at $-20^{\circ} \mathrm{C}$ using a $\mu-24$ bioreactor (applikon Biotechnology, Netherlands).

\section{Spectrophotometric determination of total CART and CHLS content}

The quantitative determination of CARS and CHLS in leaves extracts of $P$. spinosa has been conducted by the methodology of Lichtenthaler [23]. The results are then expressed in $\mathrm{mg} / 100 \mathrm{~g}$ of extract.

\section{Antioxidant activity}

In attempt to have a full profile of antioxidant capacity of chlorophylls extract from P. spinosa leaves, we have used methods based on two different modes of action: (1) hydrogen transfer (HAT) in term of 1,1-diphenyl-2picrylhydrazyl (DPPH) and 2,2 -azino-bis(3-ethylbenzothiazoline-6-sulphonic acid (ABTS) radical scavenging activities and (2) single electron transfer (SET) as determined by ferric reducing antioxidant power (FRAP) assay.

\section{Scavenging ability of DPPH radical}

DPPH test was carried out according to the modified method of Jiménez-Escrig et al. [24]. About $3.9 \mathrm{~mL}$ of DPPH solution in $\mathrm{MeOH}$ was added to $100 \mu \mathrm{L}$ of different concentrations of sample extract $(1,3,7$ and $13 \mathrm{mg} / \mathrm{mL}$ ), and then the tubes were shaken gently by vortex and put in dark place for $10 \mathrm{~min}$. The absorbance of the mixture was recorded by UV-spectrophotometer at $580 \mathrm{~nm}$. The antioxidant activity of the extract was calculated by using the following formula:

$$
\text { \%Inhibition } \left.=\left[\left(\mathrm{A}_{\text {standard }}-\mathrm{A}_{\text {extract }}\right) / \mathrm{A}_{\text {standard }}\right)\right] \times 100 .
$$

where $\mathrm{A}_{\text {extract }}$ was the absorbance of samples and $\mathrm{A}_{\text {standard }}$ the absorbance of MeOHic DPPH solution. The percentage of DPPH remaining $\left(\% \mathrm{DPPH}_{\mathrm{rem}}\right)$ was calculated using the equation below:

$$
\% \mathrm{DPPH}_{\text {rem }}=[\mathrm{DPPH}]_{\mathrm{t}} /[\mathrm{DPPH}]_{0} \times 100
$$

where $[\mathrm{DPPH}]_{0}$ is the concentration of DPPH without the sample extract and $[\mathrm{DPPH}]_{t}$ at is the concentration of DPPH after the reaction.

\section{Scavenging ability of ABTS radical}

The antioxidant activity by ABTS assay was measured by the method of Re et al. [25], as described below. After the preparation of the radical (ABTS + ) $(7 \mathrm{mM}$ ABTS stock solution and $2.45 \mathrm{mM}$ potassium persulfate), the mixture was incubated for $16 \mathrm{~h}$. After that, the solution was diluted with ethanol to an absorbance of $0.700 \pm 0.050$ at $734 \mathrm{~nm}$. One milliliter of ABTS $\bullet$ + solution was added to $100 \mu \mathrm{L}$ of the tested sample and vortexed thoroughly. The reactive mixture was left in the dark at room temperature for $2.5 \mathrm{~min}$ and the absorbance was recorded at $734 \mathrm{~nm}$.

\section{Ferric reducing antioxidant power (FRAP assay)}

Antioxidant power was tested by FRAP assay according to Thaipong et al. [26] method. Three stock solutions were previously prepared: $300 \mathrm{mM}$ acetate buffer ( $\mathrm{pH} 3.6$ ); $10 \mathrm{mM}$ of 2,4,6-tris(2pyridyl)-s-triazine (TPTZ) solution in $40 \mathrm{mMHCl}$; and $20 \mathrm{mM} \mathrm{FeCl}_{3}$ solution in distilled water. A fresh solution was prepared by mixing 
$25 \mathrm{~mL}$ acetate buffer, $2.5 \mathrm{~mL}$ TPTZ solution and $2.5 \mathrm{~mL} \mathrm{FeCl} 3$ solution. In a reaction tube, $150 \mu \mathrm{L}$ of extract was allowed to react with $2850 \mu \mathrm{L}$ of the FRAP working solution for 4 min at room temperature in the dark. The reading of the absorbance was done at $593 \mathrm{~nm}$.

For all tests, Trolox was used as a standard, and the results were expressed as micromole Trolox equivalent antioxidant capacity per $\mathrm{Kg}$ of dry weight $(\mu \mathrm{mol} \mathrm{TEAC} / \mathrm{Kg} \mathrm{DW})$.

\section{Mineral salts analysis}

Mineral composition of leaves of the studied plant has been determined by Emission Spectrometer Induced Couple Plasma (ICP) (HORIBA JobinYvon, model LAST 2, France). The reagents used for the digestion are concentrated $\mathrm{HNO}_{3}$ (Plasma Pure quality, Brand: SCP SCIENCE) and concentrated $\mathrm{H}_{2} \mathrm{O}_{2}$ (Suprapure quality, Brand: MERCK). Once treatment is complete, the sample made up to mark with ultrapure quality water.

\section{Statistical analysis}

All the experiments were conducted in triplicate and the results were expressed as mean \pm standard deviation (SD). Statistical analysis was performed by analysis of variance with ANOVA and Tukey's test in the JMP 10 software from SAS Institute Inc. (Cary, NC, USA). Correlation between CHLS and CART content and antioxidant activity was performed by XLSTAT-pro7.5. Differences were considered to be significant at $\mathrm{p}<0.05$.

\section{Results and discussion}

\section{Optimization of solvent extraction}

Seven different extraction solvents, acetone $100 \%$, aqueous acetone $80 \%$, diethyl ether, ethanol $95 \%$, MeOH $90 \%$ and $\mathrm{MeOH} 100 \%$, were used to select the best solvent for pigments extraction from P. spinosa leaves. The results were presented in Table 1 , it was clearly shown that the type of solvent significantly influenced $(\mathrm{p}<0.05)$ the CARS and CHLS yields from leaves of P. spinosa.

Table 1: Influence of solvent on extraction efficiency of carotenoids and chlorophylls from P. spinosa leaves.

\begin{tabular}{|c|c|c|c|c|}
\hline & \multicolumn{2}{|c|}{ Photosynthetic pigments } & \multicolumn{2}{|l|}{$\left(\mathrm{mg} / 100 \mathrm{~g}_{\mathrm{dw}}\right)$} \\
\hline & $\begin{array}{l}\text { CARS } \\
\left(\mu \mathrm{g} / 100 \mathrm{~g}_{\mathrm{dw}}\right)\end{array}$ & CHLA & $\begin{array}{l}\text { CHLB } \\
\left(\mathrm{mg} / 100 \mathrm{~g}_{\mathrm{dw}}\right)\end{array}$ & $\mathrm{CHLA}+\mathrm{CHLB}$ \\
\hline D Ether & $21.819 \pm 0.000^{c}$ & $77.279 \pm 0.00^{c}$ & $24.854 \pm 0.000^{\mathrm{d}}$ & $102.132 \pm 0.000^{\mathrm{d}}$ \\
\hline Hexane & $10.666 \pm 0.330^{\mathrm{d}}$ & $32.786 \pm 3.057^{\mathrm{d}}$ & $2.554 \pm 0.964^{\mathrm{e}}$ & $35.340 \pm 2.162^{\mathrm{e}}$ \\
\hline EtOH 95\% & $35.062 \pm 0.612^{\mathrm{b}}$ & $226.271 \pm 0.601^{\mathrm{a}}$ & $123.439 \pm 0.871^{\mathrm{b}}$ & $349.710 \pm 0.327^{a}$ \\
\hline Ace $100 \%$ & $394.43 \pm 0.611^{\mathrm{a}}$ & $198.956 \pm 1.773^{b}$ & $101.855 \pm 0.857^{c}$ & $300.811 \pm 2.620^{c}$ \\
\hline Ace $80 \%$ & $363.37 \pm 0.312^{\mathrm{a}}$ & $224.286 \pm 5.601^{\mathrm{a}}$ & $123.483 \pm 1.339^{\mathrm{b}}$ & $347.769 \pm 6.326^{\mathrm{a}}$ \\
\hline $\mathrm{MeOH} 100 \%$ & $22.512 \pm 0.730^{c}$ & $226.183 \pm 5.602^{\mathrm{a}}$ & $131.179 \pm 1.458^{\mathrm{ab}}$ & $357.362 \pm 7.047^{\mathrm{a}}$ \\
\hline $\mathrm{MeOH} 90 \%$ & $24.894 \pm 2.856^{c}$ & $194.815 \pm 3.538^{b}$ & $133.624 \pm 7.879^{a}$ & $328.439 \pm 5.780^{b}$ \\
\hline
\end{tabular}

Results are expressed as $\mathrm{mg} / 100 \mathrm{mg} \mathrm{dw}$. Values are mean of three determinations; values marked by the same letter are not significantly different $(p>0.05)$.

\section{The effect of extraction solvents on total carotenoids yield}

Compared with other solvents, acetone (80-100\%) is the best one for the extraction of CARS from leaves of $P$. spinosa (Table 1$)$. There is no significant difference $(\mathrm{p}>0.05)$ between the extraction yield obtained by pure acetone and that obtained by acetone $80 \%(/ 100 \mathrm{~g} \mathrm{dw})$. These are in agreement with those reported by Warkoyo and Saati [27] and Nobre et al. [28] on their study on seaweed pigment and Haematococcus pluvialis. Furthermore, Denery et al. [29] have also reported that acetone is the best solvent for extracting carotenoids from of Haematococcus pluvialis and Dunaliella salina. Amin et al. [10] have reported that the carotenoid content was 
found highest in all acetone extracts of three plants (Triticuma estivum, Spinaciaoleracea, Chromolaena odorata). Moreover, Suzuki and Shioi [30] have extracted more carotenoids by acetone (80\%) than by hot water from major teas. Thus, the effectiveness of extraction of a substance is determined by the properties of both solute and solvent [27]. Indeed, aqueous acetone is the best extraction solvent as it extracts most photosynthetic pigments $[31,32]$.

\section{The effect of extraction solvents on chlorophylls yield}

The selection of the solvent to promote the extraction is a very important issue since it determines the degree of affinity to the chemical composition of the substances to be extracted. Apart from the dissolution ability towards the compounds to be extracted and quantified, the solvent also plays an important role in cell lysis. It is clear that chlorophyll has been detected in all the solvents, with no significant difference ( $p>0.05$ ) between ethanol 95\%, $\mathrm{MeOH} 100 \%$ and acetone $80 \%\left(349.71 \pm 0.33 ; 357.36 \pm 7.04 ; 347.77 \pm 6.33 \mathrm{mg} / 100 \mathrm{~g}_{\mathrm{dw}}\right.$, respectively). Aqueous acetone is the most widely used solvent because it allows better stability for CHLA compared to methanol.

Johan et al. [33, 34] (please remove the refernce number 34) have reported that acetone results in higher CHLA concentration. Indeed, acetone gave the highest extraction efficiency for total pigments in the green algae [29] and in red seaweed [27]. Furthermore, chlorophyll content was found highest in acetone extract of Triticuma estivum, Spinaciaocelera, Eupatorium odoratum [10]. The effectiveness of extraction of a substance is determined by the match between the natural properties of the solute with a similar solvent that dissolves like them because of their polarity [27]. Based on these data, aqueous acetone $80 \%$ was selected as the best solvent for the extraction of pigments from leaves of the studied plant.

Carotenoids content of the leaves of the studied plant $(36.337 \mathrm{mg} / 100 \mathrm{~g}$ of $\mathrm{dw})$ is higher than that of some plants which are known by their nutritional and medicinal importance such as B. oleracea $(27.8 \mathrm{mg} / 100 \mathrm{~g}$ of $\mathrm{dw})$, Amaranthus sp. (24.6 mg/100g of dw), A. polygonoides $(20.6 \mathrm{mg} / 100 \mathrm{~g}$ of dw), P. crispum $(18.4 \mathrm{mg} / 100 \mathrm{~g}$ of $\mathrm{dw})$, B. diffusa $(2.80 \mathrm{mg} / 100 \mathrm{~g}$ of $\mathrm{dw})$, B. chinensis $(1.50 \mathrm{mg} / 100 \mathrm{~g}$ of $\mathrm{dw})$, C. annuum $(3.79 \mathrm{mg} / 100 \mathrm{~g}$ of $\mathrm{dw}), \mathrm{I}$. pes-tigridis (4.31 mg/100 g of dw), L. sativa $(2.87 \mathrm{mg} / 100 \mathrm{~g}$ of $\mathrm{dw})$, P. oleracae ( $4.20 \mathrm{mg} / 100 \mathrm{~g}$ of $\mathrm{dw})$, T. indica $(4.77 \mathrm{mg} / 100 \mathrm{~g}$ of $\mathrm{dw})$ [32].

Compared with some fruits and vegetables known to be rich in carotenoids (carrot: $10.432 \mathrm{mg} / 100 \mathrm{~g}$ fresh weight, spinach: $10.75 \mathrm{mg} / 100 \mathrm{~g}$ fresh weight, respectively), $P$. spinosa had a relatively high concentration of these compounds, which corresponds to half $(5.65 \mathrm{mg} / 100 \mathrm{~g}$ fresh weight) of the latter, but it remains higher than that of apricots $(3.69 \mathrm{mg} / 100 \mathrm{~g})$ [34].

As for chlorophylls $(\mathrm{CHLa}+\mathrm{b})$, the content of the leaves of P. spinosa $(347.769 \pm 6.326 \mathrm{mg} / 100 \mathrm{~g} \mathrm{dw})$, is higher than that reported for some selected leafy vegetables (cv. Anivip: $328.05 \mathrm{mg} / 100 \mathrm{~g} \mathrm{dw}$, cv. Monivip: $200.44 \mathrm{mg} / 100 \mathrm{~g} \mathrm{dw}$, Dandelion: $248.25 \mathrm{mg} / 100 \mathrm{~g} \mathrm{dw}$, Garden rocket: $359.62 \mathrm{mg} / 100 \mathrm{~g} \mathrm{dw}$ and Wild rocket: $303.23 \mathrm{mg} / 100 \mathrm{~g} \mathrm{dw})[35]$.

\section{Antioxidant activity}

The antioxidant activity of pigments extract (CRTS and CHLS) from P. spinosa was evaluated by three tests. As it is shown in Figure 1, the highest activity was obtained with DPPH test $\left(127.522 \pm 1.406 \mathrm{mmol} \mathrm{ET/Kg} \mathrm{Kw}_{\mathrm{d}}\right)$ followed by that of ABTS method $\left(104.827 \pm 1.222 \mathrm{mmol} \mathrm{ET} / \mathrm{Kg}_{\mathrm{dw}}\right)$, and the lowest one was obtained by FRAP assay $(71.89 \pm 0.495 \pm 0.994 \mathrm{mmol} \mathrm{ET/Kg} \mathrm{dw})$.

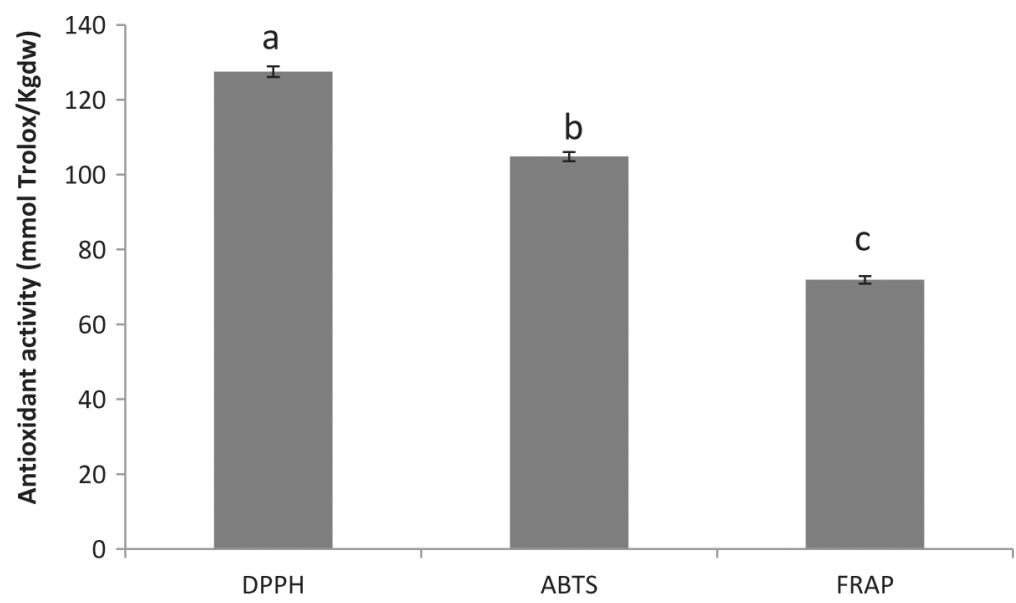


Figure 1: Antioxidant activity of pigments extracts from $P$. spinosa leaves. Results are expressed as means \pm standard deviation. Values are mean of three determinations; values marked by the same letter are not significantly different $(p>0.05)$.

In Table 2 are presented the matrices of linear correlation between pigments contents (CRTS, CHLS, CHLa and $\mathrm{CHLb}$ ) and antioxidant activity of the extract from leaves of the studied plant.

Table 2: Correlation matrix of the variables for the extract of P. Spinosa.

\begin{tabular}{llllllll}
\hline & CART & CHL a & CHL b & CHLS & DPPH & ABTS & FRAP \\
\hline CART & 1 & & & & & & \\
CHL a & $0.766^{*}$ & 1 & & & & & \\
CHL b & 0.596 & $0.965^{* *}$ & 1 & & & & \\
CHLS & $0.715^{*}$ & $0.996^{* *}$ & $0.984^{* *}$ & 1 & & & 1 \\
DPPH & 0.646 & $0.981^{* *}$ & $0.973^{* *}$ & $0.986^{* *}$ & 1 & $0.675^{*}$ & 1 \\
ABTS & $0.932^{* *}$ & $0.801^{* *}$ & $0.707^{*}$ & $0.776^{*}$ & $0.978^{* *}$ & $0.812^{* *}$ & 1 \\
FRAP & $0.771^{*}$ & $1.000^{* *}$ & $0.966^{* *}$ & $0.996^{* *}$ & 0.90 & \\
\hline
\end{tabular}

* $\mathrm{p}$ value less than $0.05,{ }^{* *} \mathrm{p}$ value less than 0.01 .

Except for the carotenoids ( $\mathrm{r}=0.646)$, a strong correlation has been found $(\mathrm{r}=0.981 ; 0.973 ; 0.986)$ between CHLa, $\mathrm{CHLb}, \mathrm{CHLS}$ and the DPPH assay. Concerning the ABTS test, a very high correlation ( $\mathrm{r}=0.932)$ has been found with carotenoids content and high correlation ( $\mathrm{r}=$ with chlorophyll contents $[0.801 ; 0.707 ; 0.776]$ for $\mathrm{CHLa}, \mathrm{CHLb}$ and CHLS, respectively). A strong correlation ( $\mathrm{r}=1 ; 0.966 ; 0.996)$ has been shown between CHLa, CHLb and CHLS, respectively, and FRAP assay, and high coefficient has been found with CART. Our results are in agreement with those reported by Mitic et al. [36, 37], in their work on the effect of food preparation technique on antioxidant activity and pigment content in some vegetables; indeed, the highest correlation was found with FRAP (0.99) assay and the lowest one was shown by DPPH and ABTS (0.68) tests.

Carotenoid and chlorophyll pigments have long been considered to be antioxidants [38] and CHLa and its oxidized derivatives had a higher antioxidant activity than other carotenoids [36]. Porphyrin seems to be an essential chemical structure for the antioxidant activity of chlorophyll, which reduced the free radicals such as DPPH; based on electron donation of antioxidants [39]. No works have been made on the antioxidant activity of the pigments of P. spinosa, the only studies reported in the literature were on their phenolic extracts.

\section{Mineral salts analysis}

From the obtained results (Table 3), we can distinguish three groups of minerals depending on whether the concentrations were greater than $1.000 \mathrm{mg} / \mathrm{kg}$ (major nutrient), between 100 and $1.000 \mathrm{mg} / \mathrm{kg}$ (minor nutrient) or less than $100 \mathrm{mg} / \mathrm{kg}$ (trace element). Comparing the minerals to each other, magnesium, calcium, phosphorus are the major elements and, iron, manganese are minor nutrients, while zinc, copper and chromium are found in traces. Calcium plays a very important role in the functioning of our body, especially in the formation of bones with the large contribution of phosphorus $[17,18]$. Concerning magnesium, it is a cofactor of enzyme systems which are involved in the biochemical reactions in the body and play an important role in the intestinal absorption [40]. Adequate iron in a diet is very critical for decreasing the incidence of anemia [41], it play a vital role in controlling various functions such as cellular respiration and the formation of the hemoglobin in red blood cells [18]. Manganese has been considered essential in human diets [17], it is found both as a structural component of some enzymes and as an activator of others [41]. Copper is a component of several enzymes (cuproenzymes) its deficiency increased incidence of several anomalies (infections, osteoporosis, hypochromic, microcytic anemia, neutropenia and bone changes) [42]. Zinc is an essential metal for the normal functioning of various enzyme systems (metalloproteinase and enzymes complexes). Indeed, this mineral plays several functions (structural, signaling, and regulatory) and its deficiency, particularly in children, can lead to loss of appetite, growth retardation, weakness and even stagnation of sexual growth. Regarding the chromium, its biological function is associated to that of insulin [18], it is an essential nutrient required for normal carbohydrate metabolism [19].

Table 3: Mineral contents of P. spinosa leaves.

\begin{tabular}{ll}
\hline Mineral salts & Concentration, $\mathbf{~ m g} / \mathbf{K g}$ of $\mathbf{~ d w}$ \\
\hline $\mathrm{Mg}$ & $6479.32 \pm 48.33^{\mathrm{a}}$
\end{tabular}




\begin{tabular}{ll}
$\mathrm{Ca}$ & $3851.88 \pm 130.63^{\mathrm{b}}$ \\
$\mathrm{P}$ & $1642.6 \pm 15.37^{\mathrm{c}}$ \\
$\mathrm{Fe}$ & $829.35 \pm 10.47^{\mathrm{d}}$ \\
$\mathrm{Mn}$ & $155.97 \pm 1.05^{\mathrm{e}}$ \\
$\mathrm{Zn}$ & $41.86 \pm 0.57^{\mathrm{f}}$ \\
$\mathrm{Cu}$ & $9.53 \pm 0.15^{\mathrm{g}}$ \\
$\mathrm{Cr}$ & $2.77 \pm 0.06^{\mathrm{h}}$ \\
\hline
\end{tabular}

Values are mean of three determinations; values marked by the same letter are not significantly different ( $\mathrm{p}>0.05)$.

Comparing our results with those of three vegetable green leaves, Dandelion, Ayoyo and Baobab [43], mineral contents are much higher in the leaves of the studied plant, with the exception for zinc and copper which are higher in Dandelion plant, from the family of Asteraceae (Compositae). Indeed, iron content of P. spinosa is much higher than that of Baobab leaves which is reported by its richness on this element. Also and with the exception for copper element, iron, zinc and manganese contents are much higher in P. spinosa leaves than in Syzygium caryophylatum and Syzygium densiflorum plants [41].

\section{Conclusion}

Different solvents were used for the optimization of the extraction of pigments from P. Spinosa plant, and acetone $80 \%$ was selected as the best one. The pigment extract showed a good antioxidant activity, which correlate positively with the content of all pigments. Through this work, we can conclude that P. spinosa is a good source of chlorophylls and carotenoids and consequently it can be considered an excellent source of antioxidants. Leaves of the studied plant are also a good sources of minerals with highest contents of $\mathrm{Ca}, \mathrm{Mg}$ and $\mathrm{P}$. As this is the first report on pigments, their antioxidant activity and mineral elements from P. spinosa plant, we can conclude that this work is a good contribution to the improvement of knowledge and data on its chemical composition and biological activity [44-63].

Author contributions: All the authors have accepted responsibility for the entire content of this submitted manuscript and approved submission.

Research funding: None declared.

Employment or leadership: None declared.

Honorarium: None declared.

Competing interests: The funding organization(s) played no role in the study design; in the collection, analysis, and interpretation of data; in the writing of the report; or in the decision to submit the report for publication.

\section{References}

[1] Barroso MF, Ramalhosa M], Alves RC, Dias A, Soares CM, Oliva-Teles MT, et al. Total antioxidant capacity of plant infusions: assessment using electrochemical DNA-based biosensor and spectrophotometric methods. Food Control 2016;68:153-61.

[2] Cazzonelli Cl, Roberts AC, Carmody ME, Pogson B]. Transcriptional control of set domain group 8 and carotenoid isomerase during arabidopsis development. Mol Plant 2010;3:174-91.

[3] Stinco CM, Benítez-Conzález AM, Hernanz D, Vicario IM, Meléndez-Martínez A]. Development and validation of a rapid resolution liquid chromatography method for the screening of dietary plant isoprenoids: carotenoids,tocopherols and chlorophylls. ] Chromatogr A 2014;1370:162-70.

[4] Stahl W, Sies H. Antioxidant activity of carotenoids. Mol Aspects Med 2003;24:345-51.

[5] Wang L, Liu Y. Optimization of solvent extraction conditions for total carotenoids in rapeseed using response surface methodology. Natural Science 2009;1:23-9.

[6] Aparicio-Ruiz R, Gandul-Rojas B. Decoloration kinetics of chlorophylls and carotenoids in virgin olive oil by autoxidation. Food Res Int 2014;65, Part B:199-206.

[7] Bakó E, Deli ], Tóth G. HPLC study on the carotenoid composition of Calendula products. ] Biochem Biophys Methods 2002;53:241-50.

[8] Ingkasupart P, Manochai B, Song WT, Hong JH. Antioxidant activities and lutein content of 11 marigold cultivars (Tagetes spp.) grown in Thailand. Food Sci Technol 2015;35:380-5.

[9] Straumite E, Kruma Z, Caloburda R. Pigments in mint leaves and stems. Agron Res 2015;13:1104-11. 
[10] Amin Mir M, Kumar N, Dogra P, Ahmad B. Analysis on the food value and chlorophyll contents of various plant species of Dehradun. AJRBPS 2014;2:150-8.

[11] Pohndorf RS, Jr TRS C, Pinto LA. Kinetics and thermodynamics adsorption of carotenoids and chlorophylls in rice bran oil bleaching. ] Food Eng 2016;185:9-16.

[12] Chen PX, Tang Y, Marcone MF, Pauls PK, Zhang B, Liu R, et al. Characterization of free, conjugated and bound phenolics and lipophilic antioxidants in regular- and non-darkening cranberry beans (Phaseolus vulgaris L.). Food Chem 2015;185:298-308.

[13] Pathan A, Kamble A, Chowdhury S, Laware S. Sequential extraction and quantification of Tinospora cordifolia leaf pigments and metabolites. Int ] Curr Microbiol App Sci 2015;4:638-44.

[14] Telgenhoff D, Lam K, Ramsay S, Vasquez V, Villareal K, Slusarewicz P, et al. Influence of papain urea copper chlorophyllin on wound matrix remodeling. Wound Rep Reg 2007;15:727-35.

[15] Tachino N, Guo D, Dashwood WM, Yamane S, Larsen R, Dashwood R. Mechanisms of the in vitro antimutagenic action of chlorophyllin against benzo[a]pyrene: studiesof enzyme inhibition, molecular complex formation and degradation of the ultimate carcinogen. Mutat Res 1994;308:191-203.

[16] Dashwood R, Yamane S, Larsen R. Study of the forces stabilizing complexes between chlorophylls and heterocyclic amine mutagens. Environ Mol Mutagen 1996;27:211-8.

[17] Imelouane B, Tahri M, Elbastrioui M, Aouinti F, Elbachiri A. Mineral contents of some medicinal and aromatic plants growing in eastern morocco. J Mater Environ Sci 2011;2:104-11.

[18] Ansari ]A, Ahmad MK, Verma AK, Fatima N, Khan H], Waseem M, et al. Microwave assisted determination of minerals and toxic metals in traditionally used medicinal plant Zingiber officinale roscoe by inductively coupled plasma-optical emission spectrometer. Int ] Adv Res 2015;3:879-87.

[19] Subramanian R, Subbramaniyan P, Raj V. Determination of some minerals and trace elements in two tropical medicinal plants. Asian Pac J Trop Biomed 2012;2:S555-S558.

[20] Wu Q-X, Shi Y-P, Jia Z-J. Eudesmane sesquiterpenoids from the Asteraceae family. Nat Prod Rep 2006;23:699-734.

[21] Hegazy A, Boulos L, Kabiel H, Sharashy O. Vegetation and species altitudinal distribution in Al-Jabal Al-Akhdar landscape, Libya. Pak ] Bot 2011;43:1885-98.

[22] Lichtenthaler HK, Buschmann C. Extraction of phtosynthetic tissues: chlorophylls and carotenoids. Curr Protoc Food Anal Chem 2001;1:F4.2.1-F4.2.6.

[23] Lichtenthaler HK. Chlorophylls and carotenoids: pigments of photosynthetic biomembranes. In: Lester Packer, Roland Douce, editors. Methods in enzymology, vol. 148. Academic Press, 1987:350-82.

[24] Jiménez-Escrig A, Jiménez-Jiménez I, Sánchez-Moreno C, Saura-Calixto F. Evaluation of free radical scavenging of dietary carotenoids by the stable radical 2, 2-diphenyl-1-picrylhydrazyl. J Sci Food Agric 2000;80:1686-90.

[25] Re R, Pellegrini N, Proteggente A, Pannala A, Yang M, Rice-Evans C. Antioxidant activity applying an improved ABTS radical cation decolorization assay. Free Radic Biol Med 1999;26:1231-7.

[26] Thaipong K, Boonprakob U, Crosby K, Cisneros-Zevallos L, Hawkins Byrne D. Comparison of ABTS, DPPH, FRAP, and ORAC assays for estimating antioxidant activity from guava fruit extracts. J Food Comp Anal 2006;19:669-75.

[27] Warkoyo SE. The solvent effectiveness of extraction process on seaweed pigment. Makara Teknologi 2011;15:5-8.

[28] Nobre B, Marcelo F, Passos R, Beirão L, Palavra A, Couveia L, et al. Supercritical carbon dioxide extraction of astaxanthin and other carotenoids from the microalga Haematococcus pluvialis. Eur Food Res Technol 2006;223:787-90.

[29] Denery JR, Dragull K, Tang C, Li QX. Pressurized fluid extraction of carotenoids from Haematococcus pluvialis and Dunaliella salina and kavalactones from Piper methysticum. Anal Chim Acta 2004;501:175-81.

[30] Suzuki Y, Shioi Y. Identification of chlorophylls and carotenoids in major teas by high-performance liquid chromatography with photodiode array detection. J Agric Food Chem 2003;51:5307-14.

[31] Khettaf A, Belloula N, Dridi S. Antioxidant activity, phenolic and flavonoid contents of some wild medicinal plants in southeastern Algeria. Afr ] Biotechnol 2016;15:524-30.

[32] Pasquet V, J-R C, Farhat F, Thiéry V, Piot ]-M, J-B B, et al. Study on the microalgal pigments extraction process: performanceof microwave assisted extraction. Process Biochem 2011;46:59-67.

[33] Johan F, Jafri M, Lim H, Maznah WW Laboratory measurement: chlorophyll-aconcentration measurement with acetone method using spectrophotometer, 2015:744-8.

[34] Jinasena M, Amarasinghe A, Amarasinghe B, Prashantha M. Extraction and degradation of chlorophyll $a$ and $b$ from alternanthera sessilis. J Natl Sci Found 2016;44:11-21.

[35] Stramarkou M, Papadaki S, Kyriakopoulou K, Krokida M. Recovery of functional pigments from four different species of microalgae. IOSR-JESTFT 2016;10:26-30.

[36] Mitić V, Stankov-Jovanović V, Dimitrijević M, Cvetković ], Petrović G, Stojanović G. Chemometric analysis of chlorophyll a, b and carotenoid content in green leafy vegetables. Biologica Nyssana 2013;4:45-55.

[37] Zakynthinos G, Varzakas T. Carotenoids: from plants to food industry. Current Res Nutr Food Sci 2016;4:38-51.

[38] Žnidarčič D, Ban D, Šircelj H. Carotenoid and chlorophyll composition of commonly consumed leafy vegetables in Mediterranean countries. Food Chem 2011;129:1164-8.

[39] Cervantes-Paz B, Jd] O-P, Ruiz-Cruz S, Rios-Velasco C, Ibarra-Junquera V, Yahia EM, et al. Effects of pectin on lipid digestion and possible implications for carotenoid bioavailability during pre-absorptive stages: a review. Food Res Int 2017;2:1-49.

[40] Žilić S, Janković M, Basić Z, Vančetović ], Maksimović V. Antioxidant activity, phenolic profile, chlorophyll and mineral matter content of corn silk (Zea mays L): comparisonwith medicinal herbs. J Cereal Sci 2016;69:363-70.

[41] Endo Y, Usuki R, Kaneda T. Antioxidant effects of chlorophyll and pheophytin on the autoxidation of oils in the dark. II. The mechanism of antioxidative action of chlorophyll. J Am Oil Chem Soc 1985;62:1387-90.

[42] Medjahdi B, Ibn Tattou M, Barkat D, Benabedli K. La flore vasculaire des monts des Trara (nord ouest algérien). Acta Bot Malacit 2009;34:57-75. 
[43] Batta A. A study design of clinical intervention of chromium in diabetics and its biological significance. European ] Biomed Pharm Sci 2017:4:147-51.

[44] Breinholt V, Schimerlik M, Dashwood R, Bailey G. Mechanisms of chlorophyllin anticarcinogenesis against aflatoxin $B_{1}$ : complexformation with the carcinogen. Chem Res Toxicol 1995;8:506-14.

[45] Hiraki A, Yukawa M, Kim ], Ueda S. Antiviral substance from silkworm faeces: purificationand its chemical characterization. Biol Pharm Bull 1997;20:547-55.

[46] Bouslama L, Hayashi K, Lee ]-B, Chorbel A, Hayashi T. Potent virucidal effect of pheophorbide a and pyropheophorbide a on enveloped viruses. J Nat Med 2011;65:229-33.

[47] Ozenda P. Flora and vegetation of the Sahara. Paris: CNRS, 1991.

[48] Quezel P, Santa S Nouvelle Flore de l'Algerie et des regions desertiques et meridionales, Tome II, edition CNRS, Paris, 1963. Coogle Scholar 1963:1016.

[49] Bammi ], Douira A. Contribution à la connaissance de la flore vasculaire de la forêt de l'Achach, plateau central (Maroc). Acta Bot Malacit 2004;29:23-41.

[50] Zareh MM. Synopsis of the family Asteraceae in Egypt. Int ] Agri Biol 2005;7:832-44.

[51] Francisco-Ortega ], Park S-], Santos-Guerra A, Benabid A, Jansen RK. Origin and evolution of the endemic Macaronesian Inuleae (Asteraceae): evidencefrom the internal transcribed spacers of nuclear ribosomal DNA. Biol ] Linn Soc 2001;72:77-97.

[52] Benítez G, González-Tejero M, Molero-Mesa ]. Pharmaceutical ethnobotany in the western part of Granada province (southern Spain): ethnopharmacologicalsynthesis. J Ethnopharmacol 2010;129:87-105.

[53] Agelet A, Valles ]. Studies on pharmaceutical ethnobotany in the region of Pallars (Pyrenees, Catalonia, Iberian Peninsula). Part II. New or very rare uses of previously known medicinal plants. J Ethnopharmacol 2003;84:211-27.

[54] Boudjelal A, Henchiri C, Sari M, Sarri D, Hendel N, Benkhaled A, et al. Herbalists and wild medicinal plants in M'Sila (North Algeria): anethnopharmacology survey. J Ethnopharmacol 2013;148:395-402.

[55] Bouabdelli F, Djelloul A, Kaid-Omar Z, Semmoud A, Addou A. Antimicrobial activity of 22 plants used in urolithiasis medicine in Western Algeria. Asian Pac] Trop Dis 2012;2:S530-S535.

[56] Ma] P-V, Robledo A. Anti-insect activity of plant extracts from the wild flora in southeastern Spain. Biochem Syst Ecol 1999;27:1-10.

[57] Ahmed AA, Jakupovic ], Bohlmann F. Dihydroxypallenone, a sesquiterpene with a new carbon skeleton from Pallenis spinosa. Phytochemistry 1990;29:3355-8.

[58] Appendino G, Cravotto G, Gariboldi P, Claudi F, Picci V. A sesquiterpene alcohol from Pallenis spinosa. Phytochemistry 1989;28:849-50.

[59] Appendino G, Jakupovic ], Jakupovic S. Sesquiterpenoids from Pallenis spinosa. Phytochemistry 1997;46:1039-43.

[60] Sanz JF, Marco JA. A germacrane derivative from Pallenis spinosa. Phytochemistry 1991;30:2788-90.

[61] Ahmed AA, Spaller M, Mabry T]. Flavonoids of Pallenis spinosa (Asteraceae). Biochem Syst Ecol 1992;20:785-6.

[62] Senatore F, Bruno M. Composition of the essential oil of Pallenis spinosa (L.) Cass. (Asteraceae). Flavour Frag ] 2003;18:195-7.

[63] Ravi Kumar S, Vallikannan B. Carotenoid composition and retinol equivalent in plants of nutritional and medicinal importance: efficacy of $\beta$-carotene from Chenopodium album in retinol-deficient rats. Food Chem 2010;119:1584-90. 